MINERALOGIA, 48, No 1-4: 63-69 (2017)

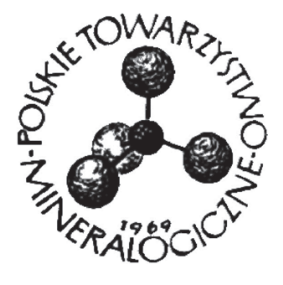

Original paper

\title{
Management of Carboniferous rock and waste mineral wool in the context of current Polish legislation
}

\author{
Dorota Tomaszewska-Krojańska ${ }^{1 *}$, Jacek Pranagal ${ }^{1}$ \\ ${ }^{1}$ University of Life Sciences in Lublin, Institute of Soil Science, Engineering and Environment Management \\ * Corresponding author \\ e-mail:dtomaszewska1989@gmail.com
}

Received: April 25, 2017

Received in revised form: August 8, 2017

Accepted: August 26, 2017

Available online: September 30, 2017

\begin{abstract}
This paper presents the legal aspects of the management of wastes that can be used as sorbents in environmental protection. The legal status of wastes with mineral characteristics - Carboniferous rock and mineral wool from horticulture - is discussed, where it is found that the number of legal acts cause difficulties in the utilisation of such wastes.
\end{abstract}

Key-words: horticultural waste mineral wool, coal gangue

\section{Introduction}

The growing population in the world and the conditions of its existence require the satisfaction of an ever-increasing demand for food products and for energy. Coal mining involves the production of large amounts of waste masses classified in group 01 (Minister of the Environment 2014). The activity of that industry is related mainly with the accumulation of huge mounds formed of rock fragments (waste-code: 0104 12), brought to the surface together with coal. They are called "burrows", "mine waste dumps", "spoil banks", or "dumps of carbonaceous rocks" and constitute a considerable environmental nuisance. Coal gangue is a mixture of organic compounds and inorganic mineral materials, e.g. shale, shale clay, and to a lesser extent mudstones and sandstone (Fabiańska et al. 2013). The chemical properties of coal gangue, its petrographic composition, and rapid 
weathering mean that it can be used for the reclamation of degraded areas (Kujawska et al. 2016).

Jabłońska et al. (2017) demonstrated that coal gangue contains a relatively welldeveloped mesoporous structure with a small content of micropores and macropores. Based on that study (Jabłońska et al. 2017), it was determined that coal gangue can be used as a cheap, disposable adsorbent for compounds with relatively large particle sizes. It can be used for the adsorption of zinc or lead from water solutions, e.g. during the preliminary treatment of industrial sewage containing heavy metals.

The rigorous legislation concerning environmental protection and the shortage of free space for storage caused a change in the existing system of mining wastes' management. The directions for the utilisation of mining wastes are given in the Directive 2006/21/EC for the management of waste from extractive industries, and its provisions have been incorporated in the Polish legislation. The document sets the minimum requirements aimed at an improvement of the methods of utilisation of wastes from the mining industry, taking into account the threats to the environment and to human health. Gruszka and PruciakKarasek (2011) pointed out that the Directive imposed a number of new obligations on mining enterprises, the realisation of which involves large financial outlays and organisational effort.

Progress in the area of agricultural and horticultural cultivation is related to the application of new technologies, methods of fertilisation and fertiliser components, and of plant protection agents. At present, special substrates are used in greenhouse production to increase the intensity of the yield, especially in horticulture. One such substrate, used most frequently, is mineral wool or its mixture with suitable additives (Nurzyński 2006). The advantages of horticultural mineral wool include high porosity and the possibility to control the $\mathrm{pH}$, temperature and moisture. Compared to organic substrates, waste mineral wool from horticulture is a chemically inert substrate, free of mineral components, and does not create conditions for the growth of pathogens in the plant root environment (Nurzyński 2004).

Current practice and experimental work (Baran 2008; Kugiela, Piekło 2012; Wróbel et al. 2013) indicate that coal gangue and waste mineral wool can be a source of sorbent applied for the improvement of soil quality. However, current legislation imposes limitations on the natural utilisation of those waste materials.

\subsection{Coal gangue}

Coal mining has always involved the production of large amounts of waste masses classified in group 01 (Minister of the Environment 2014) according to the classification given in the Regulation of the Minister of the Environment of $9^{\text {th }}$ December, 2014, concerning the cataloguing of wastes. Mining of coal are accompanied by extraction of huge amounts of rock fragments (waste-code: 0104 12) that accumulates of huge mounds. The least formalised procedure, and at the same time the most desirable in terms of environmental needs, is the utilisation of coal gangue in the process of the reclamation of degraded and devastated lands (Baic, Witkowska-Kita 2011). As pointed out by Sobko (2014), using coal gangue in agriculture requires reference to the following legal regulations: 
1. Regulation of the Minister of the Environment of $9^{\text {th }}$ September, 2002, on the standards of soil and land quality (J. of Laws No. 165, item 1359).

2. Regulation of the Council of Ministers of $2^{\text {nd }}$ January, 2007, on the requirements concerning the content of natural radioactive isotopes of potassium K-40, radium Ra226 and thorium Th-228 in raw materials and in materials used in buildings designed for habitation by people and livestock, and on the control of the content of their isotopes (J. of Laws No. 4, item 29).

3. Regulation of the Minister of the Environment of $28^{\text {th }}$ January, 2009, on the conditions that should be fulfilled when introducing wastewaters to watercourses and to the ground, and on substances harmful for the aquatic environment (J. of Laws No. 27, item 169).

The fundamental document concerning the management of extraction waste in rock mining is the Act on Mining Waste f $10^{\text {th }} \mathrm{July}$, 2008, revised in 2013 (J. of Laws 2012, item 1513). It is a separate legislative act, but it is related to the provisions contained in other acts such as the Geological and Mining Law of $11^{\text {th }}$ July, 2014 (J. of Laws 2014, item 1133); the Act on Wastes of $14^{\text {th }}$ December, 2012 (J. of Laws 2013, item 21); and a number of executive acts. As is apparent from those acts of legislation, various definitions and terms are used to refer to objects with the same function. In the mining law regulations, dumping grounds are sites where mining wastes are permanently stored (and this does not generate any positive effects for the environment), in the Act on Mining Wastes they are sites for the neutralisation of mining waste (a process that is not recovery - mining wastes are then neutral for the environment), and in the Act on Wastes they are waste dumps (in which only wastes where neutralisation is impossible should be stored). Most frequently they are not construction sites, as $\S 143$ of the Regulation of the Minister of the Economy of $8^{\text {th }}$ April, 2013, on the detailed requirements concerning the operation maintenance of strip mines (J. of Laws 2013, item 1008), stipulates that the formation of dumping grounds or dumps is conducted in accordance with technical documentation approved by the maintenance manager of the mining company. The above information shows that the definitions are mutually contradictory, and no application for valuable mining wastes is found outside of mines.

Difficulties in the implementation of the provisions of the Act on Mining Waste in strip mines (open-cast mines) are also caused by the fact that in the process of extraction and processing of the material mined, large quantities of overlying earth and rock masses are accumulated that also have a significant utility value. They can constitute both a commercial product and waste. Produced extraction waste is determined by the overlay above the deposit. The amount depends on the geological structure of the deposit and its parameters, and not on the activities of the enterprise. The recovery of mining wastes is profitable only in the case of the existence of a demand for it, which is also a matter of market conditions. To avoid the requirements concerning the recovery of wastes, enterprises treat waste earth and rock masses as raw materials or products. In such a case, the provisions of Art. 7 of the Act on Extraction Waste, allowing the storage of contaminated soil and mining waste only for a specific limited period of time, do not apply.

For open-cast mining activity, the possibility of waiver of application of the law on mining waste in a situation when for soil and rock masses the conditions and method of 
management are defined in the Mining Plant Operations Plan should be considered as the most significant change in legislation. Every mining company has the obligation to elaborate such a document. Until now, the waivers of applicability of the law on mining wastes have not included the provision that a decision approving the Mining Plant Operations Plan could change the actual formal status of earth or rock masses displaced in relation to the extraction of material from the deposit. This means that a mining enterprise can determine, in the Mining Plant Operations Plan, the conditions and method of management of earth and rock masses displaced because of the extraction of the mined material, and that this would provide sufficient grounds for the actual management of those masses. They will be exempt from the applicability of both the Act on Wastes and the Act on Mining Wastes. Whereas, the management of "waste soil" will be defined in the descriptive part of the Mining Plant Operations Plan and in the appended maps. Strippings dumped within a mining area, constituted of earth or rock masses removed from above the deposit but solely for the purpose of enabling the extraction of usable mined material, have become exempt from the provisions of the Act on Mining Waste (Ptak, Kasztelewicz 2013). To conduct the exploitation of deposits in a considered manner, efforts should be made to eliminate the terms "waste" and "mining waste" from mining company documentation, which could be classified more neutrally as "earth" and "rock masses" (overlay included). The change of such provisions should be made in the Mining Plant Operations Plan and does not require any prior changes in the legislation.

\subsection{Mineral wool}

In modern greenhouses, cultivation on specially adapted substrates is used for the purpose of intensifying yields (Hoffmann et al. 2013). One of the substrates used most frequently in horticulture is mineral wool or its mixture with suitable additives (Nurzyński 2006). It is used in a single or maximum of two production cycles, and is accumulated at the sites of horticultural production (Gilewska 2005). The basic component of mineral wool is magmatic volcanic rock - basalt or diabase, ground together with limestone or coke and melted at a temperature of $1600-2000^{\circ} \mathrm{C}$. The molten rock mass is poured onto fast rotating spinning heads or rollers, producing fibres with diameters in the order of individual $\mu \mathrm{m}$, and then pressed into sheets. Typical mineral wool is composed of 5\% solid phase (fibres) and $95 \%$ pores of various diameter (Stępowska 2003).

The current legislation actually leaves this waste outside of the general records. This results from the fact that the producers of agriculture and horticulture with the soil-less method have not been obligated to report on the amounts of material used and on its utilisation (Hoffmann et al. 2014); hence, the difficulty in the classification of mineral wool sheets in a suitable group of waste (Minister of the Environment 2014). The Regulation of the Minister of the Environment (2014) does not specify all the kinds of waste that can appear in horticulture, but only classifies wastes in groups with regard to the source of origin. In accordance with this rule, waste mineral wool sheets can be classified as waste from hydroponic cultures under waste-code 020183 . However, due to the frequent changes to the legislation and the lack of a uniform procedure, there is no specified mode of classification of waste mineral wool. The lack of clarity in the entire Polish law causes a diversity of interpretations. For example, in the paper by Nowak et al. (2013), the authors 
refer to regulations obsolete for 3 years, e.g. the Regulation of the Minister of Health of $28^{\text {th }}$ September, 2005 (J. of Laws 2005 No. 201, item 1674), which was repealed on $15^{\text {th }}$ June 2010. As a result of this situation, it is difficult to find, in both the Polish and foreign literature, an elaboration that would indicate a currently possible solution for the utilisation of superfluous horticultural substrates of mineral wool. According to Hoffmann et al. (2014), the law permits the utilisation of that waste through its introduction to soil after prior processing (removal of polyethylene foil and fragmentation of the sheets). However, this requires the obtainment of an appropriate permit, for which the producers of vegetables cannot apply as they do not meet the relevant legal requirements. The recipient of such wastes can only be an enterprise. It is described in view of the Regulation of the Minister of the Environment (2016) of $10^{\text {th }}$ November, 2015, on the list of the kinds of wastes that individual persons or organisation entities that are not enterprises can recover for their own needs, and on the allowable methods for their recovery. Waste with the code number 0201 83 has not been included in the Regulation in question (J. of Laws 2016, item 93). Waste mineral wool has also not been specified in the Regulation of the Minister of the Environment of $11^{\text {th }}$ May, 2015, on the recovery of wastes outside of installations and devices (J. of Laws 2015, item 796). But outside of Poland, various methods have been developed for the recycling of mineral wool that can be conducted and performed by the producer (Papadopoulos et al. 2008). Probably, an obligation of waste mineral wool utilisation by its producers, and its inclusion in the regulation of the Minister of the Environment (2014), would enforce suitable actions to also be undertaken in Poland, especially as mineral wool from hydroponic cultivations is a valuable waste material. Research reports indicate that mineral wool is characterised by a high water-holding capacity (approximately 82\%) and very good capillary properties (Piróg 1999). In addition, it contains composition nutrients that have not been used by plants, and it is enriched in organic matter from the residues of plants that have been cultivated on those substrates (Baran 2008; Hoffmann et al. 2013).

\section{Conclusions}

The large number of legal regulations, their frequent changes and difficult interpretation are a major problem for entrepreneurs. Good solutions that would facilitate the management of Carboniferous rock would be to a) classify it as relocated and removed earth masses, b) accept that this waste is a by-product, or c) certify the loss of the status of a waste. A strategy for the loss of the status of a waste should also be developed for waste mineral wool. The aspects described herein, concerning the management of Carboniferous rock and waste mineral wool, may contribute to legislative changes. New regulations could facilitate the procedure of reclassifying certain wastes into the category of usable products.

\section{References}

Act of $10^{\text {th }}$ July 2008 on extractive waste (J. of Laws 2008 No. 138, item 865).

Act of $16^{\text {th }}$ November 2012 amending the law on Extraction of Waste and some other laws (J. of Laws 2012, item 1513).

Act of $14^{\text {th }}$ December 2012 on waste (J. of Laws 2013, item 21).

Act of $11^{\text {th }}$ July 2014 amending the Geological and Mining Law (J. of Laws 2014, item 1133). 
Baran, S. (2008). Possibilities of the use of Grodan mineral wool to form water properties in soils and grounds. Zeszyty Problemowe Postępów Nauk Rolniczych, 533, 15-19. [In Polish with English summary].

Baic, I., \& Witkowska-Kita, B. ( 2011). Technologies of utilisation of wastes from hard coal mining - diagnosis of current state, estimation of innovation, and SWAT analysis. Rocznik Ochrona Środowiska, 13, 1315-1327. [In Polish].

Council of Ministers (2007). Regulation of $2^{\text {nd }}$ January 2007 on the requirements concerning the content of natural radioactive isotopes of potassium K-40, radium Ra-226 and thorium Th-228 in raw materials and in materials used in buildings designed for habitation by people and livestock and on the control of the content of their isotopes (J. of Laws 2007 No. 4, item 29).

Directive 2006/21/EC of the European Parliament and of the Council of 15 March 2006 on the management of waste from extractive industries and amending Directive 2004/35/EC.

Fabiańska, M. J., Ciesielczuk, J., Kruszewski, L., Misz-Kennan, M., Blake, D. R., Stracher, G., \& Moszumańska, I. (2013). Gaseous compounds and efflorescences generated in self-heating coal-waste dumps - a case study from the Upper and Lower Silesian Coal Basins (Poland). International Journal of Coal Geology, 117, 247261. DOI: 10.1016/j.coal.2013.05.002.

Gilewska, M. (2005). The usefulness of rock wool waste for reclamation of post-mining land. Zeszyty Problemowe Postępów Nauk Rolniczych, 506, 151-156. [In Polish with English summary].

Gruszka, Z., \& Pruciak-Karasek, K. (2011). Utilisation of mining wastes at the Jastrzębska Spółka Węglowa S.A. scope of activity and new obligations resulting from implementation of the Act on mining wastes. $25^{\text {th }}$ Conference - Issues related to energy raw materials and energy in national economy, 9-12 October 2011 (pp. 69-81). Zakopane, Poland. [In Polish].

Hoffmann, K., Huculak-Mączka, M., Justyniarski, A., \& Kaniewski, M. (2013). Physicochemical evaluation of horticultural mineral wool waste. Proceedings of ECOpole, 7(2), 587-591. DOI: 10.2429/proc.2013.7(2)077.

Hoffmann, J., Huculak-Mączka, M., Surowiak, A., Surowiak, S., \& Surowiak, A. (2014). Today a difficult waste tomorrow raw material. Recycling, 1, 22-23. [In Polish].

Jabłońska, B., Kityk, A. V., Busch, M., \& Huber, P. (2017). The structural and surface properties of natural and modified coal gangue. Journal of Environmental Management, 190, 80-90. DOI: 10.1016/j.jenvman.2016.12.055.

Kugiel, M., \& Piekło, R.( 2012). Directions in the management of mining wastes at HALDEX S.A. Górnictwo $i$ Geologia, 7(1), 133-145 [In Polish].

Kujawska, J., Pawłowska, M., Wójcik K., Baran, S., Żukowska, G., \& Pawłowski, A. (2016). Application of Exploratory Waste and Compost from Municipal Waste for the Production of Soil-Like Materials for Reclamation of Degraded Areas. Annual Set The Environment Protection, 18(2), 709-721. [In Polish with English summary].

Ministry of the Environment (2002). Regulation of $9^{\text {th }}$ September 2002 on the standards of soil and land quality (J. of Laws 2002 No. 165, item 1359).

Ministry of the Environment (2009). Regulation of $28^{\text {th }}$ January 2009 on the conditions to be met for the introduction of wastewater into waters or to land and on substances harmful to the aquatic environment (J. of Laws 2009 No. 27, item 169).

Ministry of the Environment (2014). Regulation of $9^{\text {th }}$ December 2014 on catalogue of wastes (J. of Laws 2014, item 1923).

Ministry of the Environment (2015). Regulation of $11^{\text {th }}$ May 2015 on the recovers of wastes outside of installations and devices (J. of Laws 2015, item 796).

Ministry of the Environment (2016). Regulation of $10^{\text {th }}$ November 2015 on the list of types of waste that natural persons or non-business entities may recover for their own needs and acceptable recovery methods (J. of Laws 2016, item 93).

Ministry of Health (2005). Regulation of $28^{\text {th }}$ September 2005 on the list of dangerous substances and their classification and labelling (J. of Laws 2005 No. 201, item 1674).

Ministry of Economy (2013). Regulation of $8^{\text {th }}$ April 2013 on detailed requirements for the operation of an opencast mining plant (J. of Laws 2013, item 1008).

Nowak, D., Jasiewicz, Cz., \& Szczerbińska-Byrska, M. (2013). Environmental aspects of use, development and disposal of mineral wool in the context of environmental resources pollution by waste retardation. Inżynieria Ekologiczna, 34, 198-205. [In Polish with English summary].

Nurzyński J. (2004). Effect of nutrient concentrations in mineral wool, peat and sand substrates on greenhouse tomato yield. Roczniki Akademii Rolniczej w Poznaniu. Ogrodnictwo, 37, 261-268. [In Polish with English summary]. 
Nurzyński J. (2006). Yielding and chemical composition of greenhouse tomato grown in ecological substrates. Acta Agrophysica, 7(3), 681-690. [In Polish with English summary].

Papadopoulos, A. P., Bar-Tal, A., Silber, A., Saha, U. K., \& Raviv, M. (2008). Inorganic and synthetic organic components of soilless culture and potting mixes. Soilless Culture. Theory and Practice. 505-543. DOI: 10.1016/B978-044452975-6.50014-9.

Piróg, J. (1999). Substrates in non-bearing crops. Fruit Vegetables Flowers, 17-18, 60-61. [In Polish].

Ptak, M., \& Kasztelewicz, Z. (2013). New solutions of mining waste management. Prace Naukowe Instytutu Górnictwa Politechniki Wrocławskiej. 136(43), 187- 194. [In Polish].

Sobko, W. (2014). Utilisation of extractive waste as the primary responsibility of the waste producer - practical activities. 20th International Fair of Road Construction AUTOSTRADA POLSKA, 14-16 May 2014 (pp 917). Kielce, Poland. [In Polish].

Stępowska, A. (2003). Physical properties of mineral wool. Hasło ogrodnicze 3, 71-73. [In Polish].

Wróbel, J. Fraś, A. Przystaś, R. Hycnar, \& J.Tora, B. ( 2013). Waste products management in the Southern Poland Coal Company (Południowy Koncern Węglowy S.A.) coal mines. Karbo, 58(3), 200-208. [In Polish]. 